\title{
$\stackrel{\approx}{\Rightarrow}$ \\ 献要 \\ 說 \\ 卒流光源を使用した \\ 活動寫眞映畫面照度の干涉に就て*
}

\author{
正會員 閒 倉 則 之 \\ （早稻田大學電氣工學科）
}

\section{The Screen Illumination of Moving Pictures Interferred by the A. C. Light Source.}

By N. Kadokura, Member, (Waseda University)

\section{內 容 梗 概}

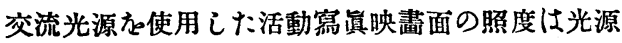
に依万脈動さ回轉遮斷器に依万遮斷作用さ干造して 明隇作用か起すものであろ。
本交は此照度の變化さ光電管及びオシログラフれ 用ひて測定した結果及び計算值童示したものである

\section{SYNOPSIS}

As the movie projector casts intermittently a series of pictures, it is necessary to shut down the light by a rotating shutter in order to keep screen clear of the unnecessary shadow accompanied by the change of action of successive pictures.

Thus the picture screen becomes dark once for each change of successive pictures. But it is common practice at present to adopt picture cycles range between 16 and 28 cycles per second.

Thus if the projected light shut down once for each picture cycle, there will arise some flickering effects of intermitted illumination.

To prevent such flickering, the present practice is to shut the light once or twice in the same picture being projected on the screen, in addition to the above said necessary shutting.

On the other hand the light intensity of the A.C. arc or A.C. incandescent lamp fluctuates with double the frequency of the supply source. Thus the alternating current used for the light source is apt to interfere with the action of rotating shutter.

The result is that the illumination of the picture screen produces some breathing effect with such low frequencies observable to the eye.

This paper describes the method of measurement of screen interference by the use of photoelectric cell and oscillograph, and also shows the calculated results.

言

活動寫顚映寫機は相連續せる個々の畫面を有するフイルムを間歇的に映寫するるのである篇各畫 面は變換働作に際して縞か映寫される筈である. 普通此縞は回轉选斷器を使用して此間の光を遮斷 して防いでるる. 從つてフィルムの一畫面が映寫される每に必ず 1 回映畫面は晤黑となる.

今日使用されてるる映寫器には各種のるのがあるが其使用されてるるフィルム畫面變換數は 1 秒

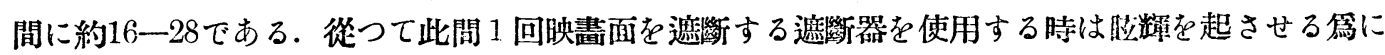
其中間に 1 回又は 2 回の光の遮砒を行ひこれを避けてるるのである.

現今映寫用の光源は主として弧燈であつて時に白熱電登が用ひられてるる，一流の劇場等に於て

\footnotetext{
*11月14日受理
} 
は電動發電機又は整流器等を使用して直流電源を作りこれに依つて弧登を點火してるろが，大多數 の映畫劇場は交流弧登を用ひて居ろ.

交流弧登は供給交流の牛周波悔に其極性を變換する故にこれから放出される光度は供給電源の周 波數の 2 倍を以て脈動する，又白熱電球もこれを交流回路に使用する場合には交流弧登とほら同一 の現象を呈する。

斯の如く脈動する光源を用ひて活動寫真を映寫する場合は光源の光度の變化と，遮斷器に依る光 の遮衒と相干步して映畫面の照度は遮断器に依る交照上外に眼で充分に感じ得る低い周波數を以て 映畫面全體の照度か增減する。

此明隇は光源の周波數及び遮斷器の回轎數が一定の場合は勿論一定の凬期を有するものであるか， 多くの場合周波數及び回轉數には多少の變化がある篇に映畫面の照度は不規則に變化する．主とし て斯樣な原因の爲に交流電源る使用した映畫面は斷えす動挌する樣に見えるのであつて，其完全な 除去又は防止の前提として此現象の詳細なる㸴究の必要は言を侯たない。

本交は此方面に關する筆者の㸴究の第一步であつて光電管及びオシログラフを使用して斯の如き 場含の照度の戀化を測定し且つ變化の各場合に對する計算の結果を示した。

测定䇪置及び方法

测定方法は干涉したる光線を光電管に投じ其光電流を堺幅器走通じてオシログラフに入れて撮影 したもので其全體の結線は第 1 圖に示す.

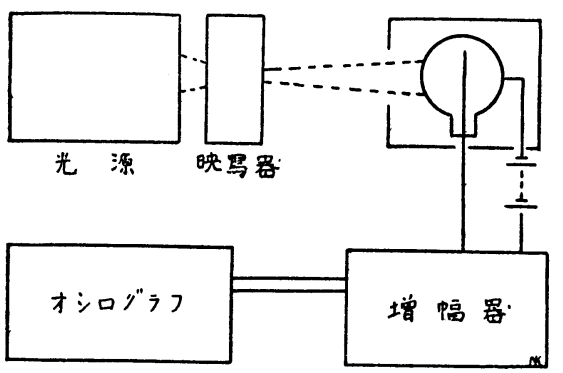

第 1 圖
光光源として使用しけ弧登器は粕通映寫機に使用さ れる手㨽弧登器である. 又白熱電球は反射鏡を有し 垂直に電球を取付ける映寫機用裝置に取付けた。

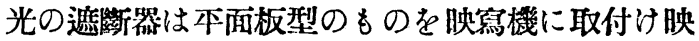
寫機を直流電動機にて回轉させて光を遮断したので ある．光は瑻際にフィルムを映寫する場合と全く同 一の方法で焦點距離 $31 / 2$ 时の映寫用レンズを通して 光電管に投じた．使用した遮断器は第 2 圖の如き開

きを有し，レンズより約 $4 \mathrm{~cm}$ の距墔に於て直徑約 $3 \mathrm{~cm}$ の光線を遮斷する.

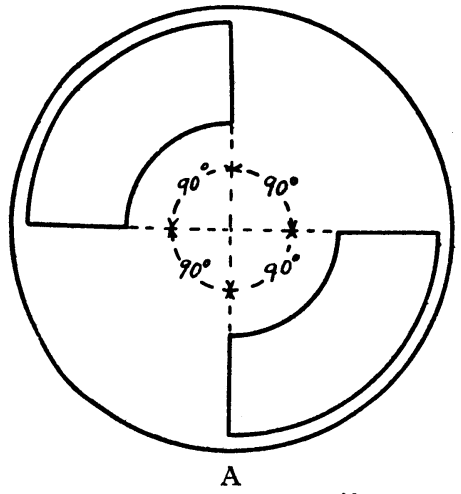

第

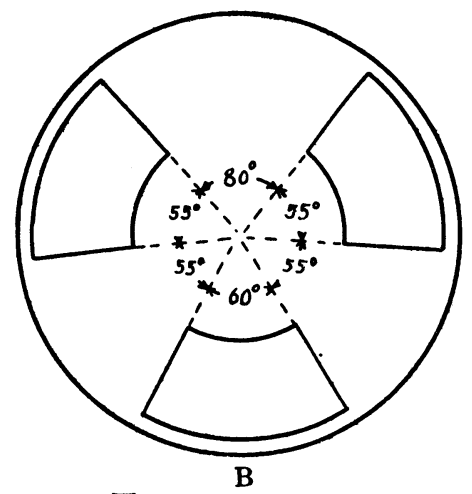

圖
第 2 圖に於てAは最も 多く使用されてをるすの で交照效果を防ぐ雼に䢥 断器本體と同一の開きを 有する狗根を 1 枚有する ものにて各々 $90^{\circ}$ の間隔 を有し全體に對し $180^{\circ} の$ 開きを有する。

B は 3 枚の狗根を有す 
るものの一種*で遮斷器本體の 角度は $80^{\circ}$ 他の $55^{\circ}$ のもの 2 枚は畩浑を防止する雼に使用される ものである.

測定は主としてAに對して行つた。

映寫機を出た光は約 $45 \mathrm{~cm}$ の距離にある直徑約 $17 \mathrm{~cm}$ の戛空光電管の員極面に投じ $6.8 \times 9.0 \mathrm{~cm}^{2}$ の 映畫面を作らせたもので第 3 圖に是等の關係を示した。

光電流は抵抗型 2 段䁌幅器に入れて增幅してオシログラフに通じた。

\section{光源の照度測定}

光源のみに依万照度の湘定は第 1 圖の接續で遮断器を使用せず光源に依る光のみを直接光電管に 投じてこれるオシログラフに入れたのである.

第 4 圖は筫驗に使用した值徑 $7 \mathrm{~mm}$ の有心電極を使用した場合の光電流 $(\mathbf{E})$, 電弧電流 $(\mathbf{I})$ 及び電 弧端子電壓 $(\mathrm{V})$ を示したもので, 其供給周波數は 50 サイクルで，電流 8.0 アムペア，電弧端子電壓 46 ヴオルトで電源電壓を直列に入れたインダクタンスで加減したちのである。千涉を測定した場合 の光源のみに依る波形の變化は常に第 4 圖の如きすのとは限らない. 即ち實際の場合に對しては電 極の材料，直徑に依り又は使用電流の大いさ，波形又は電極の相互位置等に依つて變化する。

第 5 圖は喠寫用として發筫されてるる瓦斯入タングステン電球の光の脈動を示したもので，此場 合の電球端子電痴は 100 ヴオルト，周波數は 50 サイクル，電流は 11.2 アムペフである.

\section{光の遮斷器に依る照度變化測定}

遮断器の回轉のみに依る照度の變化は第 1 圖と同一の結線で光源に白熱電球を使用しこれに直流 を通し遮断器を回轉した場合の光電流に對して浿定を行つた。

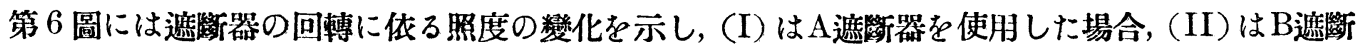
器を使用した場合である. 此場合の光源に加へた直流は 100 ヴオルト，11.2 アムペアである.

\section{干 涉 $の$ 测 定}

干涉の測定は第 1 圖の結線で光源に交流を加へ A 又は Bの遮斷器を適當な速度にて回轉させた場 合の光電流に對して行つた. 第 7 圖にはA遮斷器を使用した場合の各回轉數に對する干涉を示す.使 用した光源は直俓 $7 \mathrm{~mm}$ の有心炎素電極の弧登で，これに50サイクル 8.0 アムペアを流した. 第 7 圖 のオシログラムに對する回轉數等は約第 1 表に示すが如きものである.

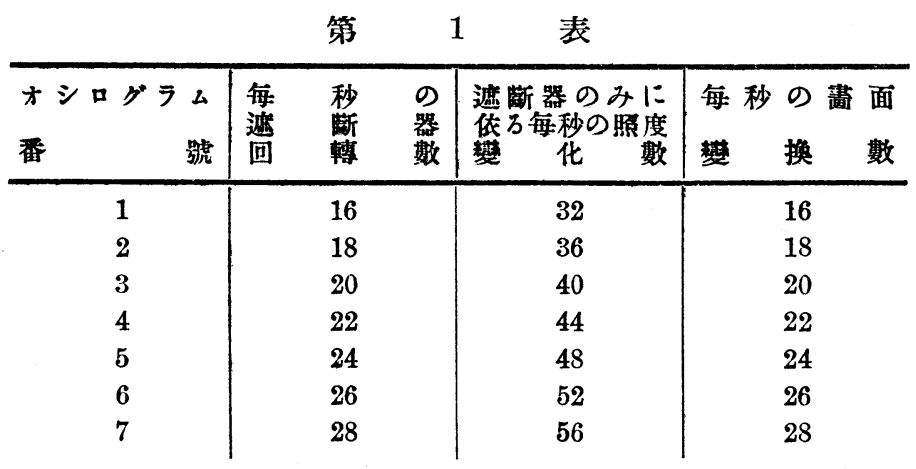

第 8 圖は B型遮斷器を使 用した場合の干涉で，其光 源は第 7 圖の場合と全 〈同 一である．此場合の回轉數 等は約第 2 表の如きもので ある.

第 9 圖は白熱電球を光源 そして使用した場合の A型 
第 2 表

\begin{tabular}{|c|c|c|c|}
\hline $\begin{array}{l}\text { オ゙ラ 番號 } \\
\text { グラ }\end{array}$ & $\begin{array}{l}\text { 遮䒨器每秒 } \\
\text { の回轉數 }\end{array}$ & 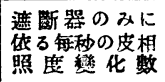 & $\begin{array}{l}\text { 每秒の畫面 } \\
\text { 變 換 數 }\end{array}$ \\
\hline 1 & 16 & 48 & 16 \\
\hline 2 & 24 & 72 & 24 \\
\hline
\end{tabular}

第 3 表

\begin{tabular}{|c|c|c|c|}
\hline $\begin{array}{l}\text { オ゙ラフ } \\
\text { グ番號 }\end{array}$ & $\begin{array}{l}\text { 遮断器毎秒 } \\
\text { の回轉數 }\end{array}$ & 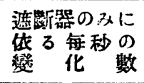 & $\begin{array}{l}\text { 敏秒の畫面 } \\
\text { 變 換 数 }\end{array}$ \\
\hline 1 & 16 & 32 & 16 \\
\hline-2 & 24 & 48 & 24 \\
\hline
\end{tabular}

遮斷器の干涉を 示したもので供給電壓は 100 ヴオルト，50サイクルである. 此場合 の回轉數等は約第 3 表に示す.

\section{照度變化に對する計算}

今光源に供給された電壓の 周波數を50 サイクルとし，これに對して $\mathrm{A}$ 型遮衒器 を使用した場合の干涉値を計算して見る。 光源のみに传る照度の戀化は次式にて表 されるものとする。

$$
I=A+A \sin w t
$$

但し $I=$ 照度, $\quad t=$ 時間 (秒), $\quad w=2 \pi f, f=$ 光度周波數 $=100$ サイクル, $A=$ 定數.

遮斷器に依る照度の戀化は時閒に對して矩班波を篇すものと假定すれば

$$
I=A+\frac{4}{\pi} A\left[\sin w t+\frac{1}{3} \sin 3 w t+\frac{1}{5} \sin 4 w t+\frac{1}{7} \sin 7 w t+\ldots \ldots\right]
$$

遮斷器に依ろ照度の 32 サイクルより，56サイクル迄の各々に對して光源の周波数 100 サイクル のものか再び同一波形のものか映寫される迄の遮斷器に依る波の波數及で時閒は第脿に示される。

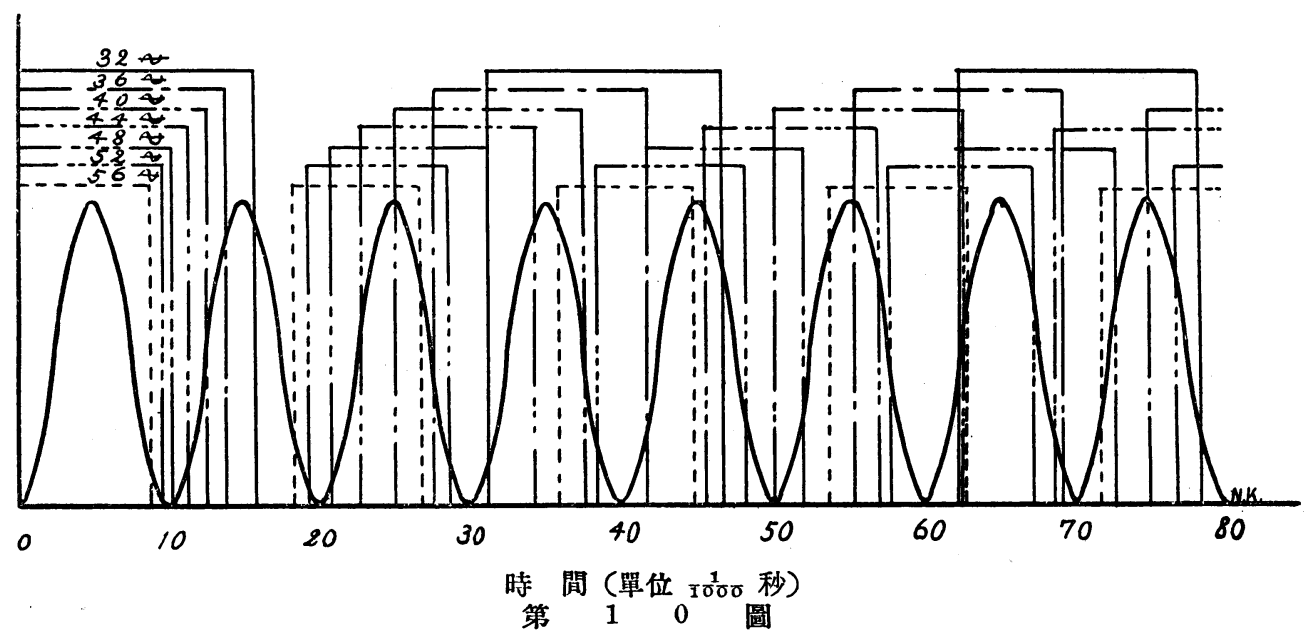

\begin{tabular}{|c|c|c|c|}
\hline $\begin{array}{c}\text { 光源の戀化 } \\
\text { サイクル }\end{array}$ & $\begin{array}{c}\text { 遮断器のみに } \\
\text { 依る照度變化 } \\
\text { サイクル }\end{array}$ & $\begin{array}{l}\text { 再び同一波形が } \\
\text { 來ろ迄の波數 }\end{array}$ & $\begin{array}{c}\text { 再ひ同一波形が } \\
\text { 來乃迄の時間 } \\
\text { (秒) }\end{array}$ \\
\hline 100 & 32 & 8 & 0.25 \\
\hline 100 & 36 & 9 & 0.25 \\
\hline 100 & 40 & 2 & 0.05 \\
\hline 100 & 44 & 11 & 0.25 \\
\hline 100 & 48 & 12 & 025 \\
\hline 100 & 52 & 13 & 0.25 \\
\hline 100 & 56 & 14 & 0.25 \\
\hline
\end{tabular}

第 4 表
各遮斷器の回轉數に對し て映寫される正弦波の矩形 波に對する相差は第10圖の 順序に變化する．第 5 表は 是等の關係をラヂァンで示 したものである. 
交流光源え使用こた活動倪真映蕃面照度の干迷に就て 正會員 門倉則之

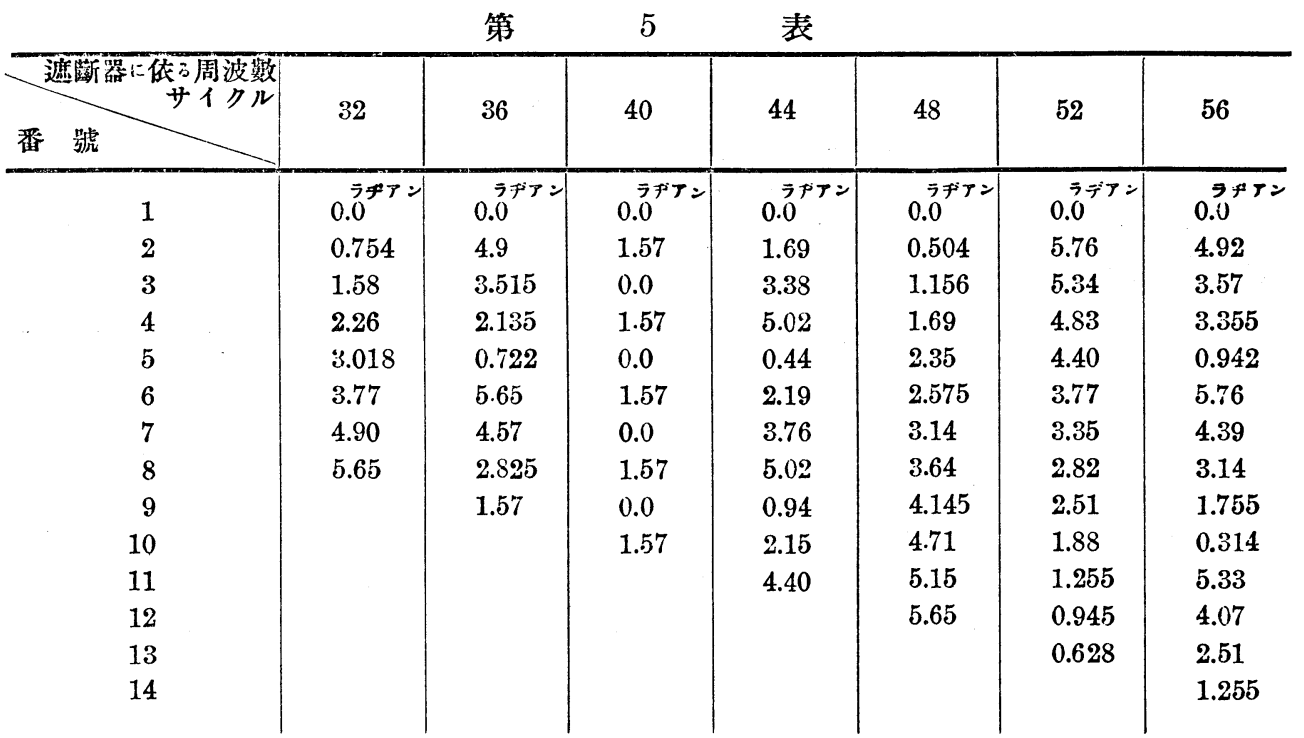

故に各遮斷器に依る各サイクル每に

$$
I=A+A \sin w t
$$

なる波形の映寫されるものは次の式で表すことが出來る。

$$
S=\int_{\theta_{1}}^{\theta_{2}} f(I) \mathrm{d} \theta
$$

此値は遮斷器の回轉數及び其相關係即ち $\theta_{1}, \theta_{2}$ の値に依つて變化する. 今各々の映寫される時 間に對する $\mathrm{S}$ を $(\mathrm{cm}) \times$ (ラヂアン) にて示せば第 11 圖の如きものをなる。

是等の干涉の場合の相關係は光源又は開閉器の極めて僅少の變化に對しても値を變へるもので, 光源の周波數を 100 サイクルとした場合，遮斷器に依る周波數 31 サイクルより 33 サイクル迄，各 0.1 サイクルに對する再び同一波形か來る迄の波數及び時間を示せば第 6 表の如くである.

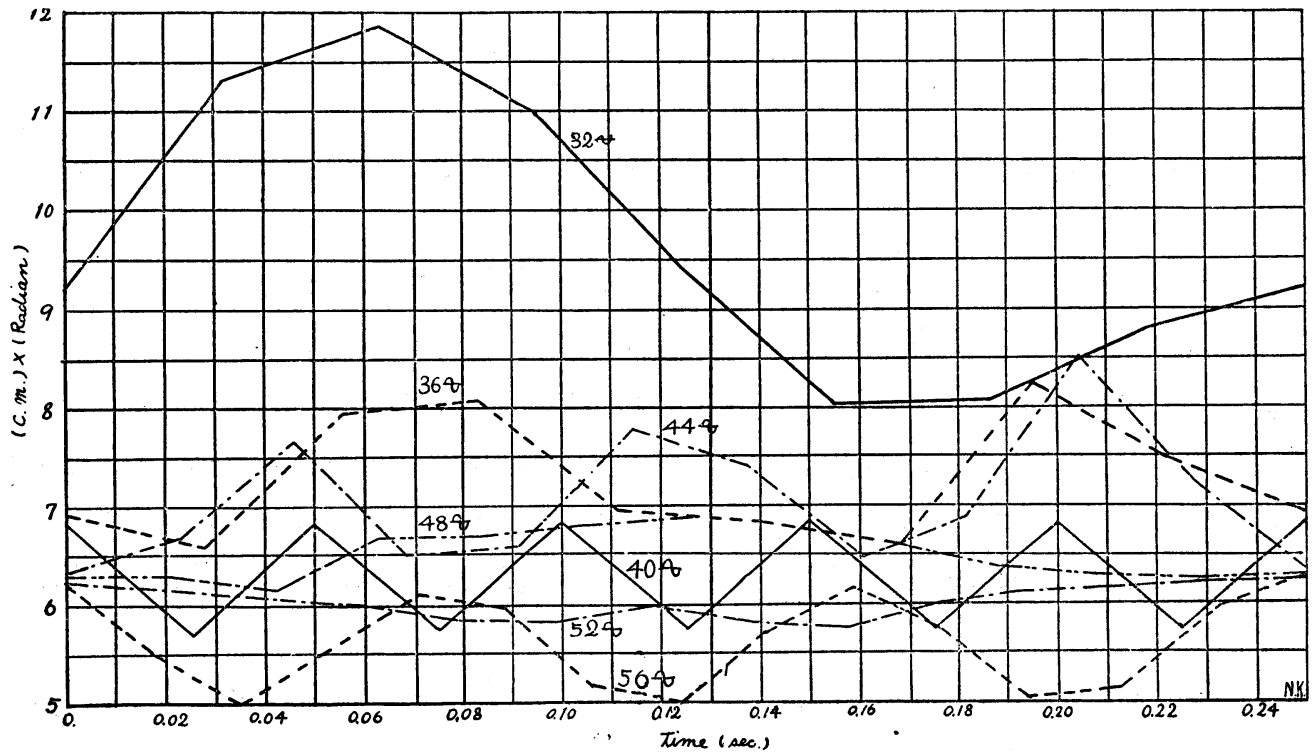


第 6 表

$\mathrm{a}=$ 再心同一波形が來万迄の波數

$\mathbf{b}=$ 再び同一波形が來万迄の時間（秒）

光源の光度周波數は每秒100サイクルさする。

\begin{tabular}{|c|c|c|c|c|c|c|c|c|}
\hline 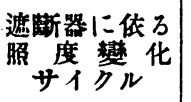 & $\mathbf{a}$ & b & $\mathbf{a}$ & b & $\mathbf{a}$ & b & $\mathbf{a}$ & b \\
\hline 31.0 & 155 & 5.0 & & & 62 & 2.0 & 31 & 1.0 \\
\hline 31.1 & & & & & & & & \\
\hline 31.2 & 156 & 5.0 & 78 & 2.5 & & & & \\
\hline 31.3 & & & & & & & & \\
\hline 31.4 & 157 & 5.0 & & & & & & \\
\hline 31.5 & & & & & 63 & 2.0 & & \\
\hline 31.6 & 158 & 5.0 & 79 & 2.5 & & & & \\
\hline 31.7 & & & & & & & & \\
\hline 31.8 & 159 & 5.0 & & & & & & \\
\hline 31.9 & & & & & & & & \\
\hline 32.0 & 160 & 5.0 & 80 & 2.5 & 64 & 2.0 & 32 & 1.0 \\
\hline 32.1 & & & & & & & & \\
\hline 32.2 & 161 & 5.0 & & & & & & \\
\hline 32.3 & & & & & & & & \\
\hline 32.4 & 162 & 5.0 & 81 & 2.5 & & & & \\
\hline 32.5 & & & & & 65 & 2.0 & & \\
\hline 32.6 & 163 & 5.0 & & & & & & \\
\hline 32.7 & & & & & & & & \\
\hline 32.8 & 164 & 5.0 & 82 & 2.5 & & & & \\
\hline 329 & & & & & & & & \\
\hline 33.0 & 165 & 5.0 & & & 66 & 2.0 & 33 & 1.0 \\
\hline
\end{tabular}

結

吉

畫面變換數を每秒 16-28 とすれば現在使用されてるろ交流光源に對して多少の照度の脈動は免 れ難い.

交流光源を使用する場合は光源自身の能率も直流光源に比して造かに低く且つ遮斷器の干涉に依 り畫面の照度は脈動する篇畫面が動搖する如くに見える。

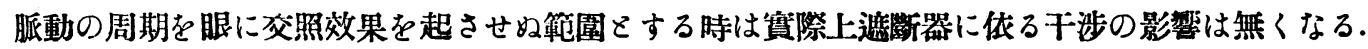
第 11 圖に依れば 50 サイクルの光源を探用した場合, 畫面變換數を 20 とすれば理論上照度の脈動の 周期は最少となり 0.05 秒を示するのである．故に50 サイクルを使用する場合に照度の干涉のみを 考へろ時は此變換數を探用すべくこれに對してフィルム摄影を第す場合も亦此變換數を探用すへ きであろ.

終りに黑川策三郎敉授の有力なる御助言及び質驗に對して努力を拂はれた伊藤弘君，小松茂君， 嘫藤進君に深く感謝の意を表する。（昭和 5 年 8 月 11 日） 


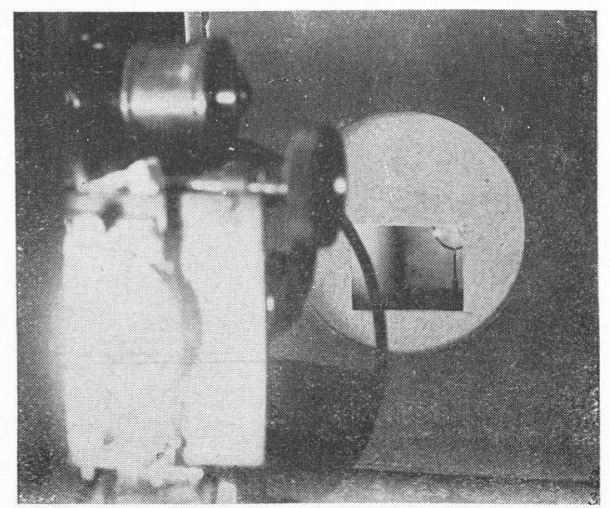

第 3 圖

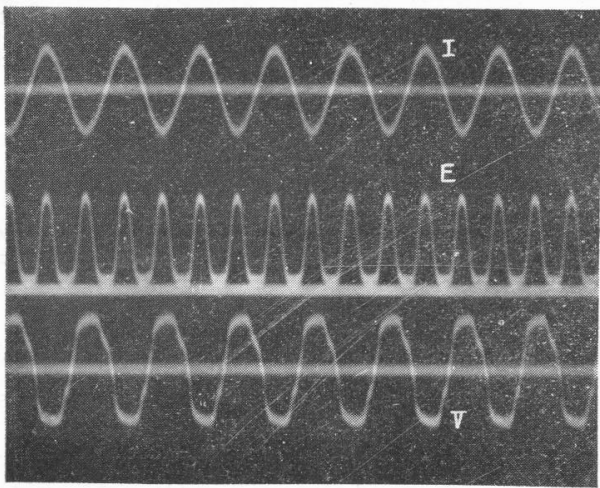

第 4 圖

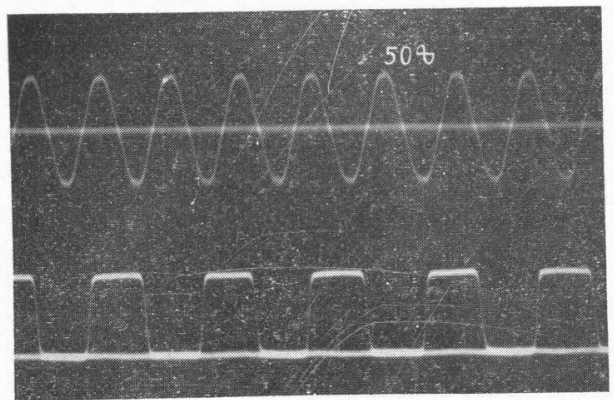

(I)

6

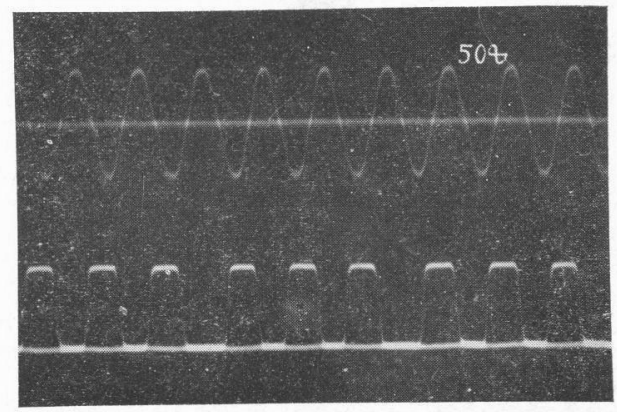

圖

(II)

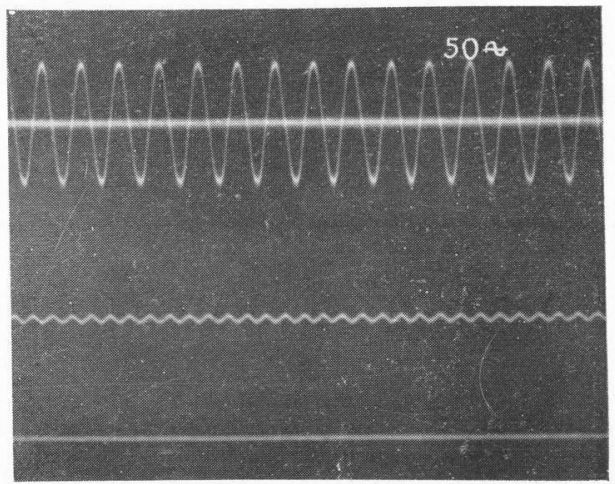

第 5 圖

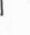




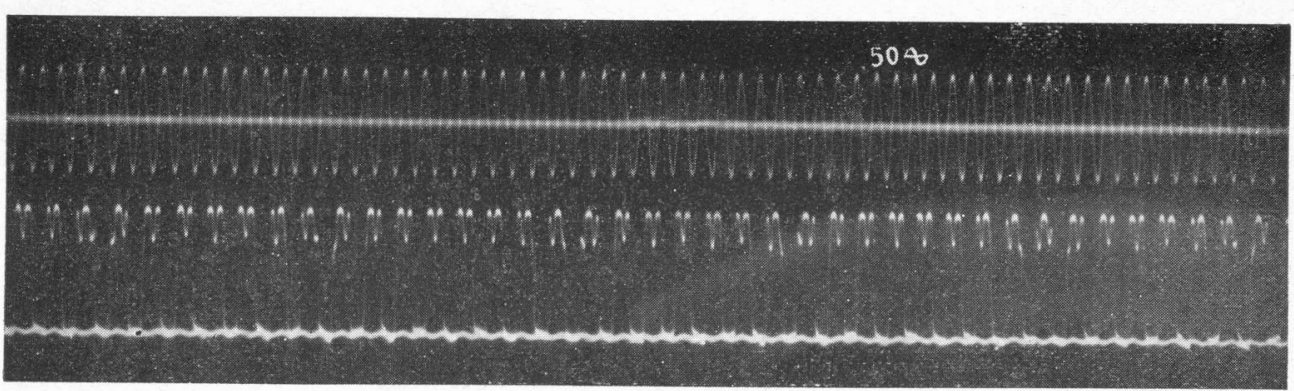

1 (遮糍器回轉數 16 r. p. s)

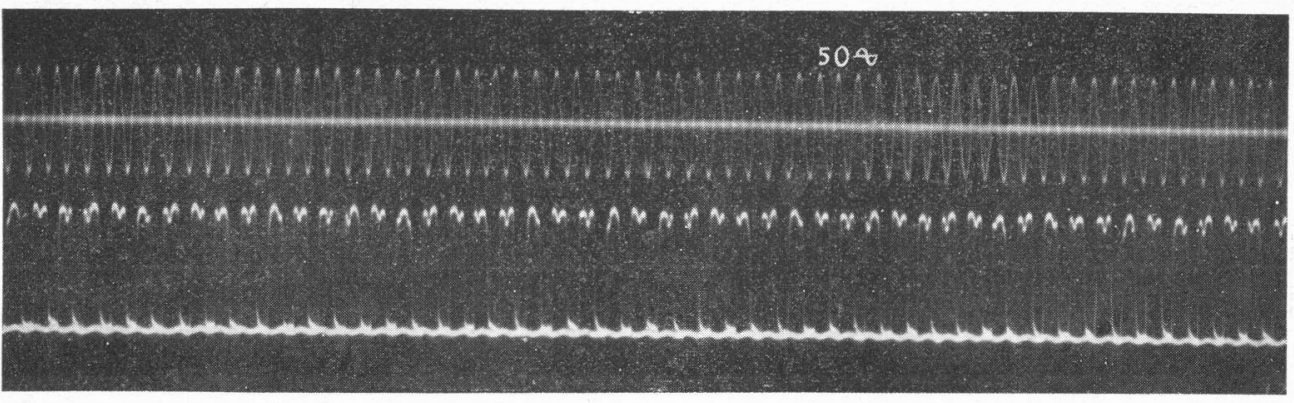

2 (遮斷器回轉數 18 r. p. s)

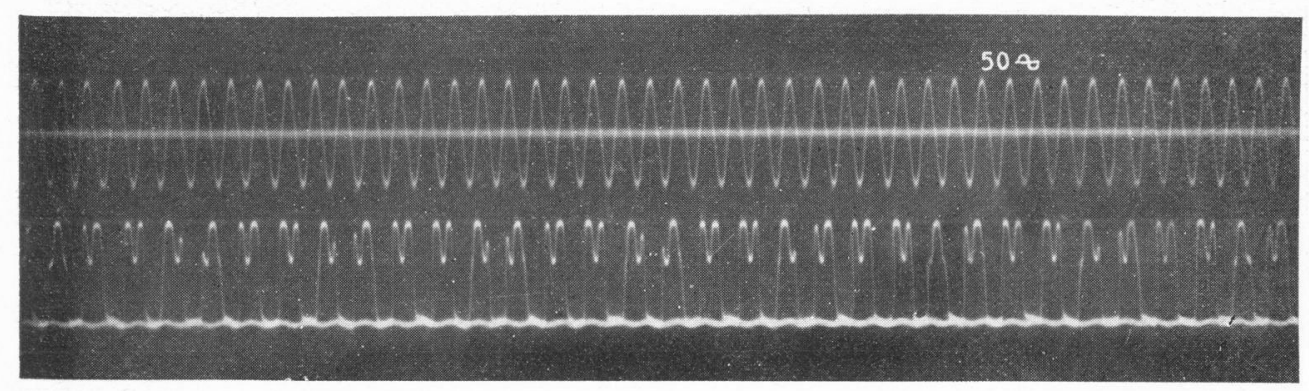

3 (遮䒿器回轉數 20 r. p. s)

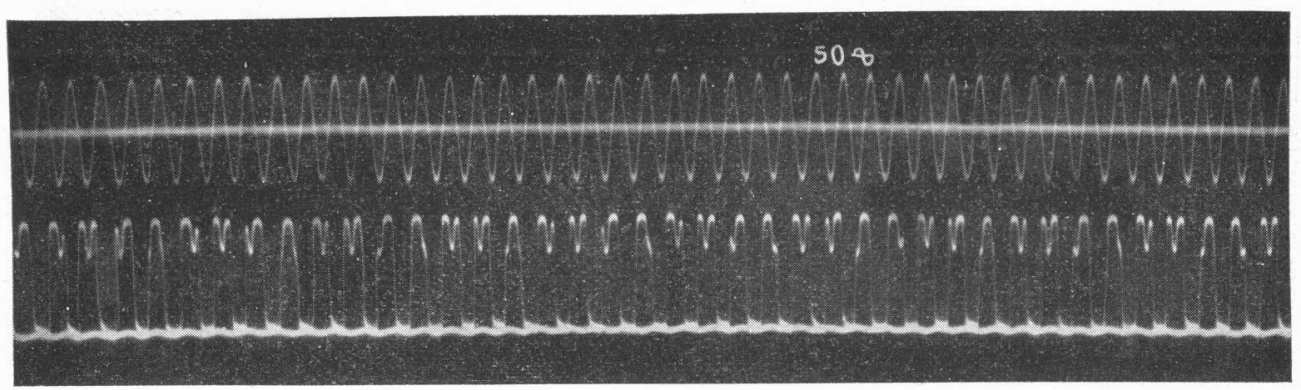

4 (遮断器回轉數 22 r. p. s) 


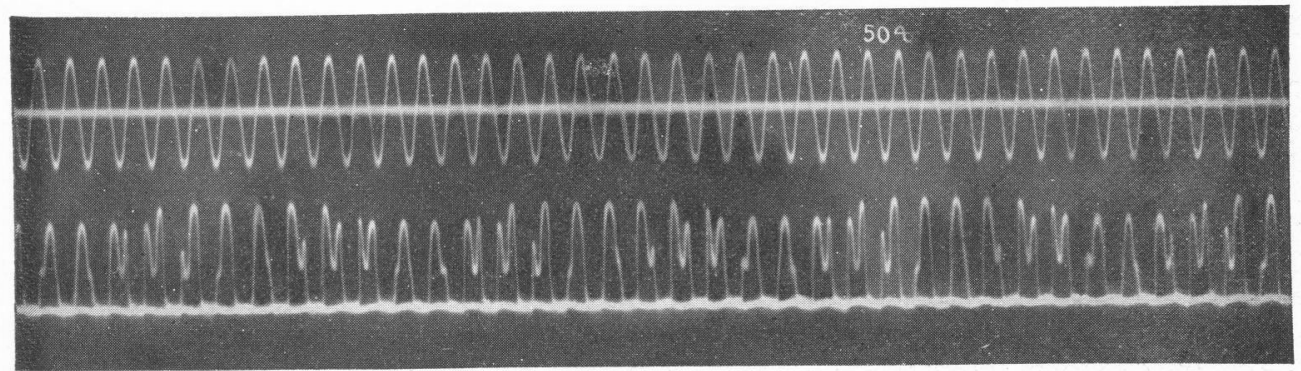

5 (遮衒器回轉數 24 r. p. s)

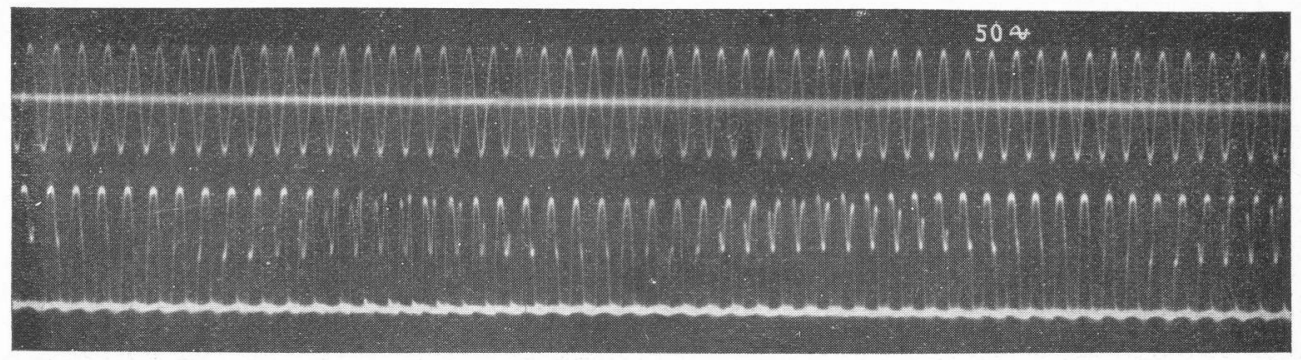

6 （遮㫁器回轉數 26 r. p. s)

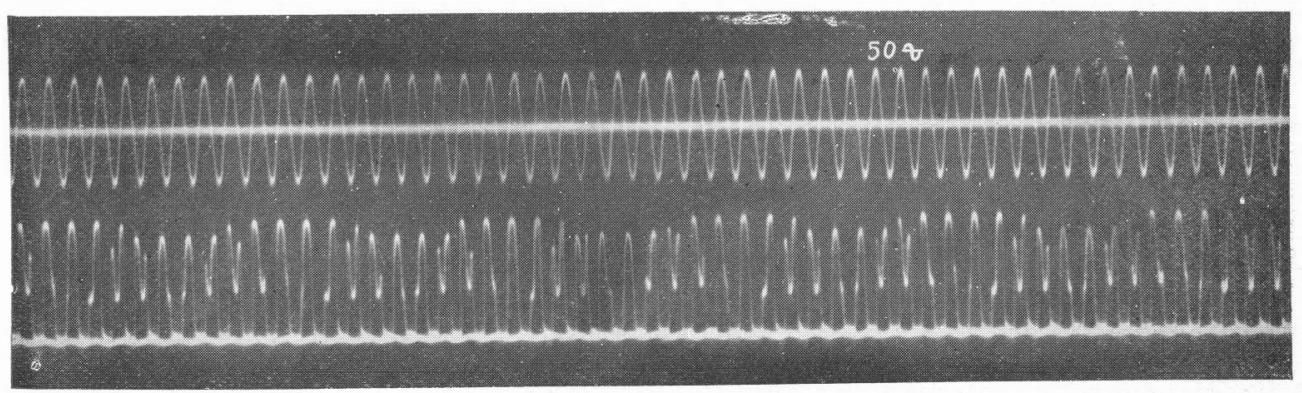

7 (遮場器回軸數 28 r. p. s)

第 8 圖

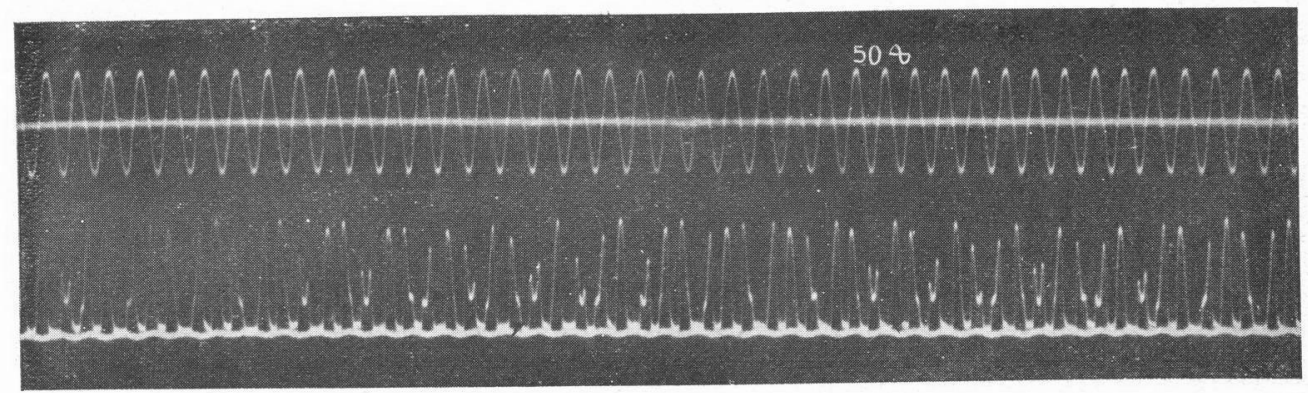

1 (遮蕬器回轉數 16 r. p. s) 


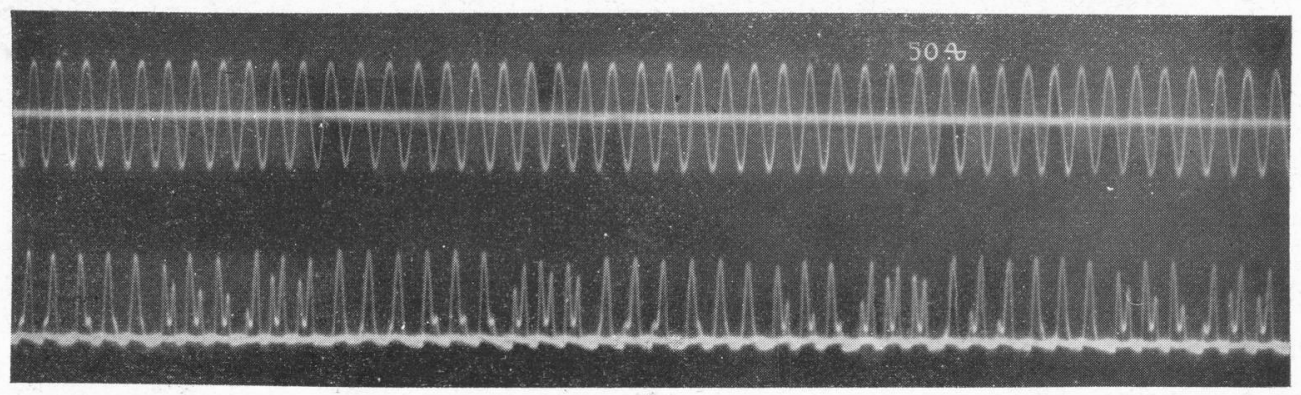

2 (遮斷器回轉數 24 r. p. s)

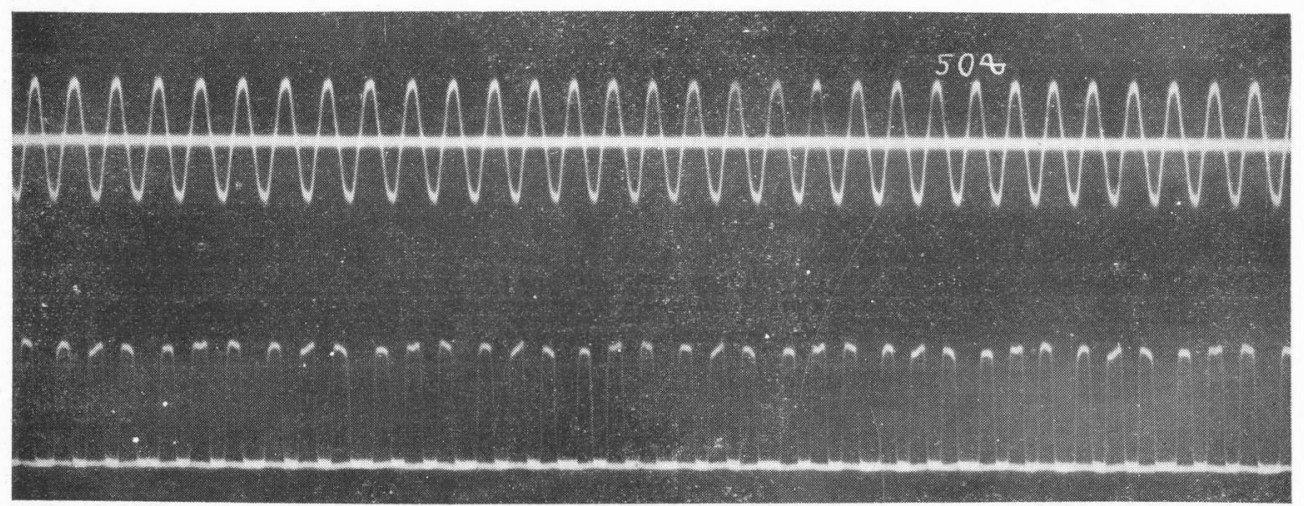

1 (遮斷器回轉數 16 r. p. s)

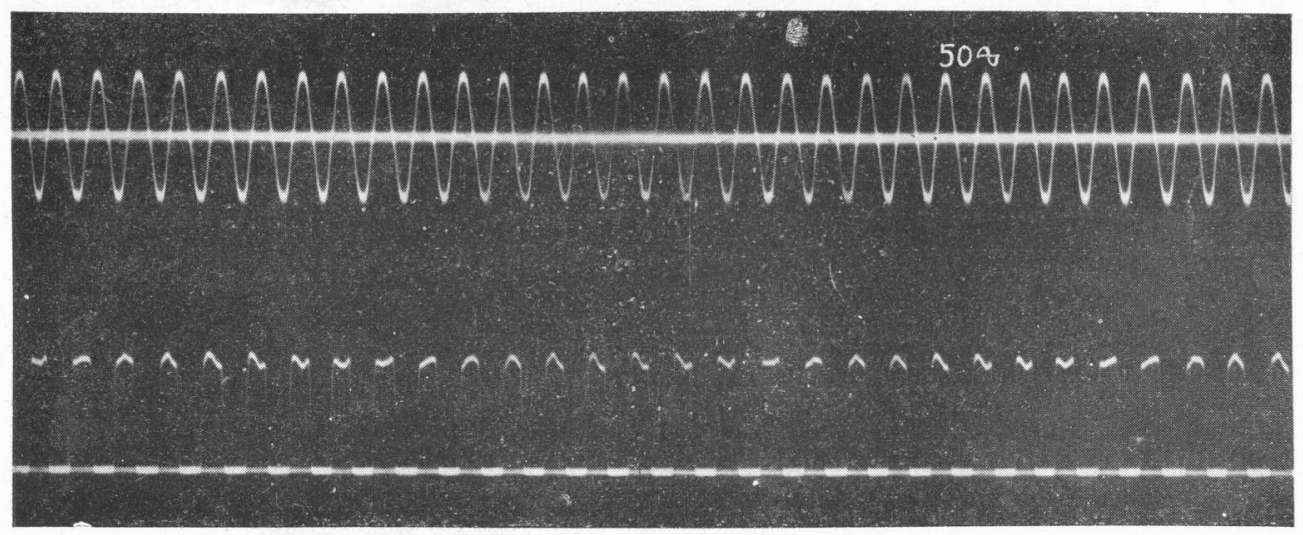

2 (遮斷器回轉數 24 r. p. s) 